\title{
DETERMINANTS OF MOTHER'S VISIT FOR HEALTH CARE AT POSYANDU: A PATH ANALYSIS EVIDENCE FROM KARANGANYAR, CENTRAL JAVA
}

\author{
Ernawati ${ }^{1,2,3)}$, Endang Sutisna Sulaeman4), Dono Indarto4) \\ 1)Vocational High School of Empat Lima Surakarta, \\ Nursing Academy Insan Husada Surakarta \\ 2)Amanah Insan Husada Sejahtera Foundation, Surakarta \\ 3)Masters Program in Public Health, Universitas Sebelas Maret \\ 4)Faculty of Medicine, Universitas Sebelas Maret, Surakarta
}

\begin{abstract}
Background: Global evidence shows that building an integrated health system with a strong foundation in primary care can result in important payoffs. It can improve population health outcomes, ensure financial protection to citizens, enhance their experience in accessing healthcare, and provide improved value for money to the system. This study aimed to investigate the determinants of mother's visit for health care at posyandu (Integrated Health Post).

Subjects and Method: This was a cross-sectional study conducted at posyandu in Karanganyar, Central Java, from April 16 to May 15, 2018. A sample of 200 mothers was selected by simple random sampling. The dependent variable was mother's visit to posyandu. The independent variables were intention, posyandu facility, peer support, and family support. The data were collected by questionnaire and analyzed by path analysis.

Results: Mother's visit to posyandu was directly and positively affected bystrong intention $(b=1.76 ; 95 \% \mathrm{CI}=0.70$ to $2.81 ; \mathrm{p}=0.001)$, posyandu facility $(\mathrm{b}=3.23$; $95 \% \mathrm{CI}=1.92$ to $4.55 ; \mathrm{p}<0.001)$, and strong peer support $(\mathrm{b}=1.95 ; 95 \% \mathrm{CI}=0.90$ to $3.01 ; \mathrm{p}<0.001)$. Mother's visit to posyandu was indirectly affected by family support through intention.

Conclusion: Mother's visit to posyandu is directly and positively affected by positive intention, posyandu facility, and strong peer support. Mother's visit to posyandu is indirectly affected by family support through intention.
\end{abstract}

Keywords: mother's visit, intention, facility, peer support, family support, posyandu

\section{Correspondence:}

Ernawati. Vocational High School of Empat Lima Surakarta, Nursing Academy Insan Husada Surakarta.Email: 3rn4wati.ew@gmail.com. 